\title{
Distribution of Rare Earth Elements in Citrus Leaves and Reference Materials (NIST SRM 1515 and ERM CD281)
}

\author{
(1) Željka Fiket,* Martina Furdek Turk
}

\author{
Ruđer Bošković Institute, Division for Marine and Environmental Research, Bijenička cesta 54, 10000 Zagreb, Croatia \\ * Corresponding author's e-mail address: zeljka.fiket@irb.hr
}

RECEIVED: July 13, 2020 * REVISED: October 21, 2020 * ACCEPTED: November 2, 2020

Abstract: The present study aims to discuss the data on levels and distribution of rare earth elements, including Y, (REYs) in leaves of three different citrus species (lemon, orange, and tangerine) and provide additional information about the major, minor and trace elements in two biological certified reference materials (CRMs), Apple leave (NIST SRM 1515) and Rye grass (ERM CD281). In all samples, element concentrations were determined by High Resolution Inductively Coupled Plasma Mass Spectrometry. The obtained data display substantial variability in the distribution of REY elements, not only between different citrus species but also between different genera of plants indicating their different uptake and accumulation abilities. Measured concentrations of REYs in citrus leaves were substantially lower compared to the literature values, although the fractionation indices were comparable. The data for CRMs provide additional information for the 14 elements in NIST SRM 1515 and the 30 elements in ERM CD281, including rare earth elements.

Keywords: citrus leaves, rare earth elements, trace elements, Apple leave (NIST SRM 1515), Rye grass (ERM CD281)

\section{INTRODUCTION}

$\mathbf{T}$ HE flowering trees and shrubs of the Citrus genus include some of the most important cultivated fruits around the world. ${ }^{[1,2]}$ Belonging to the family Rutaceae, one of the largest families of the order Sapindales, this genus encompasses about 140 genera and 1300 species; of which the most economically important are the lemon (C. xlemon), sweet orange (C. xsinensis), sour orange (C. xaurantium), tangerine ( $C$. reticulata), lime ( $C$. xaurantiifolia), grapefruit (C. xparadise), citron (C. medica) and shaddock (C. maxima). Their worldwide distribution can be attributed to their great nutritional and medicinal value and growing interest in plant-based medications. ${ }^{[3-5]}$ Citrus leaves are usually strongly fragrant, while their extracts contain many useful flavonoids and other compounds that are effective insecticides, fungicides, and medicinal agents. ${ }^{[5,6]}$

Despite their prevalence and widespread use, the literature on the chemical properties of citrus plants is relatively limited, while studies related to the multi-elemental characterization are very rare. ${ }^{[7-9]}$ However, increasing anthropogenic pressures, which inevitably condition the continuous input of various toxic elements into our environment, put this topic at the forefront and require additional studies.

Although plants do not rely on most of the transition (heavy) metals for normal plant growth and development, they can suffer serious damage if exposed to their excessive concentrations. ${ }^{[10,15-17]}$ In that terms, chemical characterization of biological samples provides insight into the concentrations of individual chemical elements, which further allows the determination of mechanisms of their uptake and accumulation as well as the assessment of anthropogenic impact on the system. ${ }^{[18,19]}$ Despite the fact that the increased use of rare earth elements for industrial and agricultural purposes portrays them as emerging pollutants, $[20,21]$ research on biological and toxicological effects of elements of this group is still rather limited. ${ }^{[22]}$

As for other trace elements, the capacity of plants or crops to accumulate REEs depends on the species and the REEs content in the substrate. ${ }^{[23]}$ The latter can be artificaly 
increased by the application of NPK or other phosphate fertilizers. Recent findings of Turra et al. ${ }^{[23]}$ suggested that under such conditions, citruses readily accumulate REE, with leaf-soil ratio up to 1.09. Unfortunately, very limited research has been done so far regarding the distribution of rare earth elements in citrus systems. ${ }^{[23]}$

The study of the distribution of the REEs in plant systems, however, goes beyond the primary interest of the determination of their total concentrations in certain plant systems. Namely, in the early 1990s, Bennet and Breen ${ }^{[24]}$ identified some notable similarities in the plant uptake mechanisms of trivalent REEs and $\mathrm{Al}^{3+}$, suggesting REEs as potential ultrastructural tracers for Al toxicity in plants. Additionally, Wei and Zhou ${ }^{[25]}$ found that free $\mathrm{Nd}^{3+}$ at low concentrations can specially bind to the high-affinity $\mathrm{Ca}^{2+}$ binding sites on the Ca-ATPase. Later, the physiological interaction of REEs with calcium (Ca), the effects of the REEs on structure and function of cytoplasm membranes, photosynthesis, hormone metabolism, and enzyme activity, and the water use efficiency have been more extensively discussed by Zhengyi et al. ${ }^{[26]}$

Although the soil analysis is still the most used tool for estimation of metal bioavailability, ${ }^{[15,17,27-29]}$ the development of fast analytical techniques for multielement analysis enhances the role of plant studies in environmental and agricultural management. Among different techniques, HR-ICP-MS has been repeatedly confirmed as a highly specific technique for multielement analysis of a large number of elements, over a wide linear range (up to 8 orders of magnitude), and in different types of samples. ${ }^{[30]}$

Moreover, the existing trends of many national and international regulations on environmental and food safety are becoming more strict, imposing lower maximum permissible levels of toxic metals in food, animal feed, soil, water, etc., and require further development of analytical techniques for fast and reliable analysis. Thereat, reference materials are considered an important tool in ensuring the quality of measurements and validation of the analytical methods. Although the biological reference standards in the field of food control and environmental biochemistry are numerous and versatile, they are very often certified for a limited set of elements, and rarely include data for rare earth elements.

Therefore, the aim of the present study is twofold. The main aim is a detailed discussion of distribution of REY in leaves of three different citrus species, previously reported by Fiket et al. ${ }^{[31]}$. An additional goal is to report on the levels of 46 major, minor, and trace elements, including REYs, in two certified reference materials, Apple leave (NIST SRM 1515) and Rye grass (ERM CD281), that are often used in food, plant or pharmaceutical studies but are certified for only a limited set of elements.

\section{METHODS}

\section{Sample Collection and Preparation}

Discussed citrus leaf samples include three different citrus species: orange, lemon, and tangerine. Details of their sampling and sample preparation are described elsewhere. ${ }^{[31]}$

In addition to leaf samples, the following certified reference materials (CRMs) were also analysed: (i) Apple leave (NIST SRM 1515, The National Institute of Standards and Technology, USA) and (ii) Rye grass (ERM CD281, IRM, Belgium).

Subsamples ( $0.05 \mathrm{~g}$ ) of CRM samples were subjected to total digestion in the microwave oven (Multiwave ECO, Anton Paar, Graz, Austria) in a one-step procedure consisting of digestion with a mixture of $6 \mathrm{~mL}$ nitric acid $\left(\mathrm{HNO}_{3}, 65 \%\right.$, traceSELECT, Fluka) and $0.1 \mathrm{~mL}$ hydrofluoric acid (HF, $48 \%$, traceSELECT, Fluka). ${ }^{[32]}$ Procedural blank solutions were prepared in the same way as sample solutions; equal volumes of an acid mixture, which have been used for sample digestion, were microwave-assisted heated in the same manner that was applied for the digestion of samples.

Prior to analysis, samples were acidified $2 \%(v / v)$ $\mathrm{HNO}_{3}$ (65\%, supra pur, Fluka, Steinheim, Switzerland), and indium (In, $1 \mu \mathrm{gL}^{-1}$ ) was added as the internal standard.

It should be noted that for both the citrus leaf samples ${ }^{[31]}$ and CRMs, the same digestion and preparation protocol was used.

\section{Sample Analysis}

The multielement analysis of prepared samples was performed by High Resolution Inductively Coupled Plasma Mass Spectrometry (HR-ICP-MS) using an Element 2 instrument (Thermo, Bremen, Germany). The typical instrument conditions and measurement parameters used throughout the work are reported elsewhere. ${ }^{[30]}$ Mass calibration of the instrument (HR-ICP-MS) was performed using a multielement solution (Merck KGaA, Darmstadt, Germany) that contains the following elements: $\mathrm{B}, \mathrm{Ba}, \mathrm{Co}, \mathrm{Fe}, \mathrm{Ga}, \mathrm{In}, \mathrm{K}, \mathrm{Li}$, $\mathrm{Lu}, \mathrm{In}, \mathrm{Rh}, \mathrm{Sc}, \mathrm{Tl}, \mathrm{U}$, and $\mathrm{Y}$.

Standards for trace element analysis were prepared by appropriate dilution of a multielement reference standard (100 $\pm 0.2 \mathrm{mg} \mathrm{L}^{-1}$, Analytika, Prague, Czech Republic) containing $\mathrm{Al}, \mathrm{As}, \mathrm{Ba}, \mathrm{Be}, \mathrm{Bi}, \mathrm{Cd}, \mathrm{Co}, \mathrm{Cr}, \mathrm{Cs}, \mathrm{Cu}, \mathrm{Fe}, \mathrm{Li}, \mathrm{Mn}$, $\mathrm{Mo}, \mathrm{Ni}, \mathrm{Pb}, \mathrm{Se}, \mathrm{Sr}, \mathrm{Ti}, \mathrm{Tl}, \mathrm{V}$, and $\mathrm{Zn}$ in which single element standard solutions of $U\left(1.000 \pm 0.002 \mathrm{~g} \mathrm{~L}^{-1}\right.$, Aldrich, Milwaukee, WI, USA), Rb (1.000 $\pm 0.002 \mathrm{~g} \mathrm{~L}^{-1}$, Aldrich, Milwaukee, WI, USA), Sb (1.000 $\pm 0.002 \mathrm{~g} \mathrm{~L}^{-1}$, Analytika, Prague, Czech Republic) and Sn (1.000 $\pm 0.002 \mathrm{~g} \mathrm{~L}^{-1}$, Analytika, Prague, Czech Republic) were added. Zirconium (1000 mg L-1, Alfa Aesar, Germany) was prepared as a separate single 
standard solution. For REEs determination, a multielement reference standard (Analytika, Prague, Czech Republic) containing $\mathrm{Ce}, \mathrm{La}, \mathrm{Nd}$, and $\mathrm{Pm}\left(100 \pm 0.2 \mathrm{mg} \mathrm{L}^{-1}\right)$ and $\mathrm{Dy}, \mathrm{Er}$, $\mathrm{Eu}, \mathrm{Gd}, \mathrm{Ho}, \mathrm{Lu}, \mathrm{Sc}, \mathrm{Sm}, \mathrm{Tb}, \mathrm{Tm}, \mathrm{Y}$, and $\mathrm{Yb}\left(20 \pm 0,4 \mathrm{mg} \mathrm{L}^{-1}\right)$ was used. For major elements determination, a multielement reference standard (Fluka, Germany) containing $\mathrm{K}, \mathrm{Mg}$, and Na was used.

All samples were analysed for the total concentration of 46 elements (Al, As, Ba, Be, Bi, Cd, Ce, Co, Cr, Cs, Cu, Dy, Er, $\mathrm{Eu}, \mathrm{Fe}, \mathrm{Gd}, \mathrm{Ho}, \mathrm{K}, \mathrm{La}, \mathrm{Li}, \mathrm{Lu}, \mathrm{Mg}, \mathrm{Mn}, \mathrm{Mo}, \mathrm{Na}, \mathrm{Nd}, \mathrm{Ni}, \mathrm{Pb}, \mathrm{Pr}, \mathrm{Rb}$, $\mathrm{Sb}, \mathrm{Sc}, \mathrm{Se}, \mathrm{Sm}, \mathrm{Sn}, \mathrm{Sr}, \mathrm{Tb}, \mathrm{Ti}, \mathrm{Tl}, \mathrm{Tm}, \mathrm{U}, \mathrm{V}, \mathrm{Y}, \mathrm{Yb}, \mathrm{Zn}$, and $\mathrm{Zr}$ ).

\section{RESULTS AND DISCUSSION}

\section{Method Validation}

Method validation for analysis of listed 46 elements in CRMs included determination of limits of detection (LOD)

Table 1. Measured element concentrations in procedural blank solutions (expressed in $\mu \mathrm{g} \mathrm{L}^{-1}$ ) and calculated limits of detection (LOD) and quantification (LOQ) (both expressed in $\mathrm{mg} \mathrm{kg}^{-1}$ ).

\begin{tabular}{cccccccc}
\hline Element & Blank & LOD & LOQ & Element & Blank & LOD & LOQ \\
\hline $\mathrm{Al}$ & 5 & 6 & 18 & $\mathrm{Mo}$ & 0.005 & 0.005 & 0.015 \\
$\mathrm{As}$ & 0.005 & 0.003 & 0.01 & $\mathrm{Na}$ & 2 & 3 & 10 \\
$\mathrm{Ba}$ & 0.1 & 0.3 & 1.0 & $\mathrm{Nd}$ & 0.002 & 0.001 & 0.003 \\
$\mathrm{Be}$ & 0.002 & 0.002 & 0.006 & $\mathrm{Ni}$ & 0.05 & 0.03 & 0.1 \\
$\mathrm{Bi}$ & 0.002 & 0.002 & 0.006 & $\mathrm{~Pb}$ & 0.05 & 0.03 & 0.1 \\
$\mathrm{Cd}$ & 0.002 & 0.002 & 0.006 & $\mathrm{Pr}$ & 0.002 & 0.001 & 0.003 \\
$\mathrm{Ce}$ & 0.002 & 0.001 & 0.003 & $\mathrm{Rb}$ & 0.01 & 0.03 & 0.1 \\
$\mathrm{Co}$ & 0.002 & 0.002 & 0.006 & $\mathrm{Sb}$ & 0.002 & 0.002 & 0.006 \\
$\mathrm{Cr}$ & 0.05 & 0.03 & 0.1 & $\mathrm{Sc}$ & 0.002 & 0.002 & 0.006 \\
$\mathrm{Cs}$ & 0.002 & 0.002 & 0.006 & $\mathrm{Se}$ & 0.04 & 0.02 & 0.06 \\
$\mathrm{Cu}$ & 0.05 & 0.03 & 0.1 & $\mathrm{Sm}$ & 0.002 & 0.001 & 0.003 \\
$\mathrm{Dy}$ & 0.002 & 0.001 & 0.003 & $\mathrm{Sn}$ & 0.005 & 0.003 & 0.01 \\
$\mathrm{Er}$ & 0.002 & 0.001 & 0.003 & $\mathrm{Sr}$ & 0.5 & 0.5 & 1.5 \\
$\mathrm{Eu}$ & 0.002 & 0.001 & 0.003 & $\mathrm{~Tb}$ & 0.002 & 0.001 & 0.003 \\
$\mathrm{Fe}$ & 2 & 3 & 10 & $\mathrm{Ti}$ & 0.5 & 0.5 & 1.5 \\
$\mathrm{Gd}$ & 0.002 & 0.001 & 0.003 & $\mathrm{Tl}$ & 0.002 & 0.001 & 0.003 \\
$\mathrm{Ho}$ & 0.002 & 0.001 & 0.003 & $\mathrm{Tm}$ & 0.002 & 0.001 & 0.003 \\
$\mathrm{~K}$ & 4 & 15 & 45 & $\mathrm{U}$ & 0.002 & 0.001 & 0.003 \\
$\mathrm{La}$ & 0.002 & 0.001 & 0.003 & $\mathrm{~V}$ & 0.002 & 0.002 & 0.006 \\
$\mathrm{Li}$ & 0.015 & 0.005 & 0.015 & $\mathrm{Y}$ & 0.002 & 0.001 & 0.003 \\
$\mathrm{Lu}$ & 0.002 & 0.001 & 0.003 & $\mathrm{Yb}$ & 0.002 & 0.001 & 0.003 \\
$\mathrm{Mg}$ & 5 & 6 & 18 & $\mathrm{Zn}$ & 2.5 & 1.5 & 4.5 \\
$\mathrm{Mn}$ & 0.1 & 0.25 & 0.75 & $\mathrm{Zr}$ & 0.05 & 0.01 & 0.03 \\
\hline & & & & & & &
\end{tabular}

and quantification (LOQ) (Table 1) as well as the demonstration of accuracy by presenting previously published data for Citrus leave $\mathrm{CRM}^{[31]}$ obtained by the above-described method. The reason for the latter is that the Citrus leave CRM is certified for all elements encompassed by this study, with exception of $\mathrm{Zr}$ (Table 2).

Measured element concentrations in procedural blank solutions and the calculated LOD and LOQ limits for all measured elements are presented in Table 1. Limits of detection and quantification were calculated, respectively, as three and ten times the standard deviation of ten consecutive measurements of the analyte concentration in the procedural blank. The LODs and LOQs range from $0.001 \mathrm{mg} \mathrm{kg}^{-1}$ to $1.5 \mathrm{mg} \mathrm{kg}^{-1}$ and from $0.003 \mathrm{mg} \mathrm{kg}^{-1}$ to $4.5 \mathrm{mg} \mathrm{kg}^{-1}$, respectively, for the trace elements (including the group of REEs), and from $3 \mathrm{mg} \mathrm{kg}^{-1}$ to $15 \mathrm{mg} \mathrm{kg}^{-1}$ and from $10 \mathrm{mg} \mathrm{kg}^{-1}$ to $45 \mathrm{mg} \mathrm{kg}^{-1}$, respectively, for minor and major elements (Table 1).

To assess the precision of the measurements, for each element a relative standard deviation (RSD) from the mean of six replicates per CRM, both NIST SRM 1515 and ERM CD281, was calculated. The obtained RSDs amounted to $7 \%$ and $9 \%$, respectively.

\section{Major, Minor and Trace Elements in CRMs}

The results of measurement of 46 elements (Al, As, Ba, Be, $\mathrm{Bi}, \mathrm{Cd}, \mathrm{Ce}, \mathrm{Co}, \mathrm{Cr}, \mathrm{Cs}, \mathrm{Cu}$, Dy, Er, Eu, Fe, Gd, Ho, K, La, Li, Lu, $\mathrm{Mg}, \mathrm{Mn}, \mathrm{Mo}, \mathrm{Na}, \mathrm{Nd}, \mathrm{Ni}, \mathrm{Pb}, \mathrm{Pr}, \mathrm{Rb}, \mathrm{Sb}, \mathrm{Sc}, \mathrm{Se}, \mathrm{Sm}, \mathrm{Sn}, \mathrm{Sr}$, $\mathrm{Tb}, \mathrm{Ti}, \mathrm{Tl}, \mathrm{Tm}, \mathrm{U}, \mathrm{V}, \mathrm{Y}, \mathrm{Yb}, \mathrm{Zn}$, and $\mathrm{Zr}$ ) in studied CRMs, associated average recovery values and calculated REY fractionation indices are shown in Table 3 and Table 4.

In Figures 1 and 2, the measured concentrations are shown as recovery ranges calculated from the average concentrations of the elements and their standard deviations. Certified values were presented in the same manner, including their uncertainties. For simplicity, the data for major, minor, and trace elements were shown separately from the REEs data.

In NIST SRM 1515, certified values are listed for only 18 out of 46 elements encompassed by the present study, while an additional 14 elements are noted only with informative values; meanwhile, the concentrations of REEs are not listed or are only informative. For this reference material, the average recoveries range from $92 \%$ and $108 \%$ (Table 3), for all measured elements listed in the reference sheet both certified and informative, and show complete overlap with the range of certified values (Figure $1 \mathrm{~b}$ and Figure $2 \mathrm{~b}$ ). Informative values are specified as mean value and $95 \%$ confidence interval.

The elements present at the lowest concentrations $\left(<0.05 \mathrm{mg} \mathrm{kg}^{-1}\right), \mathrm{Co}, \mathrm{Sb}, \mathrm{Sc}$, and $\mathrm{U}$, display the largest standard deviations. For these elements, only informative 
values are listed in the reference sheet; and on Figure 2a they are displayed as small points, instead of ranges.

Ivanova et al. ${ }^{[33]}$ reported concentrations for 31 elements in NIST SRM 1515, of which 28 are included in the present study. For the certified elements, here presented data display higher accuracy and precision than those obtained by quadrupole ICP-MS. ${ }^{[33]}$ For other elements (Be, Bi, Dy, Er, Ho, $\mathrm{Lu}, \mathrm{Pr}, \mathrm{Tl}$, and $\mathrm{Y}$ ), not included in the reference sheet, values reported by Ivanova et al. ${ }^{[33]}$ were found comparable to those obtained by HR-ICP-MS in this study, although slightly lower.
In ERM CD281, only 16 elements are stated in the reference sheet and no certified or informative values are reported for the group of REEs. For this CRM, the average recoveries range from $91 \%$ and $108 \%$ (Table 4), for all measured elements listed in the reference sheet, both certified and informative and show partial or complete overlap with the range of certified values (Figure 1c). Informative values are specified as mean value and $95 \%$ confidence interval. Despite the lack of data for this CRM in the literature, available data for Rye grass (BCR 261), obtained by

Table 2. Comparison of measured element concentrations (mean \pm standard deviation; $n=6$ ) and certified values (with associated uncertainties), expressed both in $\mathrm{mg} \mathrm{kg}^{-1}$, obtained recoveries (\%), [31] and calculated REY fractionation indices in Citrus leave (NCS ZC73018).

\begin{tabular}{|c|c|c|c|c|c|c|c|}
\hline Element & Measured & Certified value & Recovery & Element & Measured & Certified value & Recovery \\
\hline Al & $1052 \pm 30$ & $1150 \pm 100$ & 91 & $\mathrm{Tl}$ & $0.057 \pm 0.001$ & $0.06 \pm 0.008$ & 95 \\
\hline As & $0.995 \pm 0.045$ & $1.1 \pm 0.2$ & 90 & $U$ & $0.046 \pm 0.001$ & $0.045 \pm 0.01$ & 102 \\
\hline $\mathrm{Ba}$ & $97.7 \pm 2.9$ & $98 \pm 6$ & 100 & V & $1.11 \pm 0.04$ & $1.16 \pm 0.13$ & 96 \\
\hline $\mathrm{Be}$ & $0.0265 \pm 0.001$ & $0.031 \pm 0.007$ & 85 & $\mathrm{Zn}$ & $18 \pm 0.55$ & $18 \pm 2$ & 100 \\
\hline $\mathrm{Bi}$ & $0.229 \pm 0.005$ & $0.23 \pm 0.025$ & 100 & $\mathrm{Zr}$ & $1.74 \pm 0.15$ & -(a) & $-(a)$ \\
\hline $\mathrm{Cd}$ & $0.157 \pm 0.004$ & $0.17 \pm 0.02$ & 92 & Y & $0.412 \pm 0.009$ & $0.42 \pm 0.04$ & 98 \\
\hline Co & $0.21 \pm 0.012$ & $0.23 \pm 0.06$ & 91 & La & $0.534 \pm 0.017$ & $0.57 \pm 0.06$ & 94 \\
\hline $\mathrm{Cr}$ & $1.18 \pm 0.05$ & $1.25 \pm 0.11$ & 94 & $\mathrm{Ce}$ & $0.993 \pm 0.043$ & $1 \pm 0.13$ & 99 \\
\hline Cs & $0.139 \pm 0.006$ & $0.14 \pm 0.01$ & 99 & $\operatorname{Pr}$ & $0.107 \pm 0.004$ & $0.108 \pm 0.014$ & 99 \\
\hline $\mathrm{Cu}$ & $6.20 \pm 0.3$ & $6.6 \pm 0.5$ & 94 & $\mathrm{Nd}$ & $0.419 \pm 0.021$ & $0.42 \pm 0.05$ & 100 \\
\hline $\mathrm{Fe}$ & $463 \pm 15$ & $480 \pm 30$ & 96 & $\mathrm{Sm}$ & $0.081 \pm 0.006$ & $0.08 \pm 0.007$ & 101 \\
\hline K & $7189 \pm 150$ & $7700 \pm 400$ & 93 & $\mathrm{Eu}$ & $0.032 \pm 0.002$ & $0.033 \pm 0.002$ & 97 \\
\hline $\mathrm{Li}$ & $1.02 \pm 0.026$ & $1 \pm 0.1$ & 102 & $\mathrm{Gd}$ & $0.080 \pm 0.004$ & $0.081 \pm 0.01$ & 99 \\
\hline $\mathrm{Mg}$ & $2300 \pm 50$ & $2340 \pm 70$ & 98 & $\mathrm{~Tb}$ & $0.010 \pm 0.001$ & $0.011 \pm 0.001$ & 92 \\
\hline $\mathrm{Mn}$ & $29.6 \pm 0.9$ & $30.5 \pm 1.5$ & 97 & Dy & $0.057 \pm 0.004$ & $0.057 \pm 0.05$ & 100 \\
\hline Mo & $0.193 \pm 0.01$ & $0.2 \pm 0.01$ & 97 & Ho & $0.011 \pm 0.001$ & $0.011 \pm 0.001$ & 98 \\
\hline $\mathrm{Na}$ & $129 \pm 4$ & $130 \pm 20$ & 99 & $\mathrm{Er}$ & $0.026 \pm 0.002$ & $0.026 \pm 0.006$ & 101 \\
\hline $\mathrm{Ni}$ & $1.11 \pm 0.05$ & $1.1 \pm 0.055$ & 101 & $\mathrm{Tm}$ & $0.004 \pm 0.001$ & $0.0038 \pm 0.0009$ & 102 \\
\hline $\mathrm{Pb}$ & $9.74 \pm 0.25$ & $9.7 \pm 0.9$ & 100 & $\mathrm{Yb}$ & $0.026 \pm 0.001$ & $0.025 \pm 0.005$ & 103 \\
\hline $\mathrm{Rb}$ & $2.86 \pm 0.08$ & $3 \pm 0.2$ & 95 & Lu & $0.004 \pm 0.001$ & $0.0037 \pm 0.0009$ & 106 \\
\hline $\mathrm{Sb}$ & $0.176 \pm 0.008$ & $0.2 \pm 0.06$ & 88 & $\sum R E Y^{(b)}$ & 2.8 & & \\
\hline Sc & $0.137 \pm 0.006$ & $0.14 \pm 0.02$ & 98 & $\mathrm{Eu} / \mathrm{Eu}^{*(\mathrm{c})}$ & 2.02 & & \\
\hline Se & $0.17 \pm 0.01$ & $0.17 \pm 0.03$ & 100 & $\mathrm{Ce} / \mathrm{Ce}{ }^{*(\mathrm{~d})}$ & 0.80 & & \\
\hline Sn & $3.8 \pm 0.1$ & $3.8 \pm 0.5$ & 100 & $\Sigma \mathrm{LREE} / \Sigma \mathrm{HREE}^{(\mathrm{e})}$ & 14.4 & & \\
\hline $\mathrm{Sr}$ & $164 \pm 3.5$ & $170 \pm 10$ & 96 & $\mathrm{Ba} / \mathrm{Eu}^{(\mathrm{f})}$ & 3053 & & \\
\hline $\mathrm{Ti}$ & $37.8 \pm 1.5$ & $38 \pm 10$ & 99 & & & & \\
\hline
\end{tabular}

(a) - not specified.

(b) $\Sigma R E Y$ - sum of all rare earth element concentrations.

(c) Eu / Eu* - europium anomaly (Eu / Eu* = EuNASC / (SmNASC $\times$ GdNASC)0.5)

(d) Ce / Ce* - cerium anomaly (Ce / Ce* $=$ CeNASC / (LaNASC $\times$ PrNASC) 0.5$)$.

(e) $\Sigma$ LREE / $\Sigma$ HREE - ratio of sum of light rare earth and heavy rare earth element concentrations.

(f) $\mathrm{Ba} / \mathrm{Eu}-$ ratio of $\mathrm{Ba}$ and Eu concentrations. 
ICP-AES, show similar values for Eu, Ho, Lu, Nd, Tb, Y, and Yb, and higher values (up to 5 times) of other REEs. ${ }^{[34]}$

\section{Rare Earth Elements in Citrus Leaf Samples}

Concentrations of REEs $+\mathrm{Y}(\mathrm{REY})$ in all analysed samples ranged over three orders of magnitude, from $0.0003 \mathrm{mg} \mathrm{kg}^{-1}$ (Lu) to $0.646 \mathrm{mg} \mathrm{kg}^{-1}$ (La), with $\Sigma R E Y$ ranging from $0.203 \mathrm{mg} \mathrm{kg}^{-1}$ to $1.71 \mathrm{mg} \mathrm{kg}^{-1}$ (Table 5). Among them, La was present at highest levels in lemon leaf samples, representing on average
$38 \%$ of the total REY, while Ce was present at the highest level in tangerine and orange leaf samples, accounting between $33 \%$ and $38 \%$ of the total REY. Thulium and lutetium, on the other hand, exhibited the lowest values. Highest concentrations of REYs were measured in lemon leaf samples where their average $\Sigma R E Y$ value reached 1.54 $\pm 0.17 \mathrm{mg} \mathrm{kg}^{-1}$, while orange and tangerine leaves exhibited lower REY concentrations, with average $\Sigma R E Y$ values of 0.42 $\pm 0.11 \mathrm{mg} \mathrm{kg}^{-1}$ and $0.22 \pm 0.02 \mathrm{mg} \mathrm{kg}^{-1}$, respectively (Table 5). However, the measured REY concentrations in the leaf

Table 3. Comparison of measured element concentrations (mean \pm standard deviation; $n=6$ ) and certified values (with associated uncertainties), expressed both in $\mathrm{mg} \mathrm{kg}^{-1}$, obtained recoveries (\%), and calculated REY fractionation indices in Apple leave (NIST SRM 1515).

\begin{tabular}{|c|c|c|c|c|c|c|c|}
\hline Element & Measured & Certified value & Recovery & Element & Measured & Certified value & Recovery \\
\hline Al & $270 \pm 15$ & $286 \pm 9$ & 94 & $\mathrm{Tl}$ & $0.012 \pm 0.002$ & -(a) & $-(a)$ \\
\hline As & $0.035 \pm 0.002$ & $0.038 \pm 0.007$ & 92 & $U$ & $0.006 \pm 0.0006$ & $0.006^{*}$ & 100 \\
\hline $\mathrm{Ba}$ & $47.5 \pm 2$ & $49 \pm 2$ & 97 & V & $0.261 \pm 0.015$ & $0.26 \pm 0.03$ & 100 \\
\hline $\mathrm{Be}$ & $<0.002$ & -(a) & -(a) & $\mathrm{Zn}$ & $12.6 \pm 0.8$ & $12.5 \pm 0.3$ & 101 \\
\hline $\mathrm{Bi}$ & $0.011 \pm 0.002$ & $-(a)$ & -(a) & $\mathrm{Zr}$ & $0.728 \pm 0.012$ & $-(a)$ & -(a) \\
\hline $\mathrm{Cd}$ & $0.013 \pm 0.002$ & $0.013 \pm 0.002$ & 100 & Y & $9 \pm 0.5$ & -(a) & -(a) \\
\hline Co & $0.085 \pm 0.005$ & $0.09 *$ & 94 & La & $20.4 \pm 0.5$ & $20 *$ & 102 \\
\hline $\mathrm{Cr}$ & $0.3 \pm 0.02$ & $0.3^{*}$ & 100 & $\mathrm{Ce}$ & $3.05 \pm 0.2$ & $3 *$ & 102 \\
\hline Cs & $0.005 \pm 0.001$ & $-(a)$ & -(a) & $\operatorname{Pr}$ & $4.1 \pm 0.2$ & -(a) & -(a) \\
\hline $\mathrm{Cu}$ & $5.42 \pm 0.30$ & $5.64 \pm 0.24$ & 96 & $\mathrm{Nd}$ & $17.3 \pm 0.5$ & $17^{*}$ & 102 \\
\hline $\mathrm{Fe}$ & $84.1 \pm 2.5$ & $83 \pm 5$ & 101 & $\mathrm{Sm}$ & $3.1 \pm 0.1$ & $3^{*}$ & 103 \\
\hline K & $15900 \pm 250$ & $16100 \pm 20$ & 99 & $\mathrm{Eu}$ & $0.195 \pm 0.015$ & $0.2^{*}$ & 98 \\
\hline $\mathrm{Li}$ & $0.251 \pm 0.026$ & $-(a)$ & -(a) & Gd & $3 \pm 0.12$ & $3^{*}$ & 100 \\
\hline $\mathrm{Mg}$ & $2630 \pm 150$ & $2710 \pm 8$ & 97 & $\mathrm{~Tb}$ & $0.39 \pm 0.02$ & $0.4^{*}$ & 98 \\
\hline $\mathrm{Mn}$ & $51.5 \pm 2.5$ & $54 \pm 3$ & 95 & Dy & $1.85 \pm 0.2$ & $-(a)$ & $-(a)$ \\
\hline Mo & $0.094 \pm 0.006$ & $0.094 \pm 0.013$ & 100 & Ho & $0.31 \pm 0.02$ & $-(a)$ & -(a) \\
\hline $\mathrm{Na}$ & $22.6 \pm 1.1$ & $24.4 \pm 1.2$ & 93 & $\mathrm{Er}$ & $0.64 \pm 0.05$ & -(a) & -(a) \\
\hline $\mathrm{Ni}$ & $0.95 \pm 0.05$ & $0.91 \pm 0.12$ & 104 & $\mathrm{Tm}$ & $0.048 \pm 0.003$ & -(a) & -(a) \\
\hline $\mathrm{Pb}$ & $0.45 \pm 0.01$ & $0.47 \pm 0.024$ & 92 & $\mathrm{Yb}$ & $0.28 \pm 0.013$ & $0.3^{*}$ & 93 \\
\hline $\mathrm{Rb}$ & $9.6 \pm 0.5$ & $10.2 \pm 1.5$ & 94 & Lu & $0.032 \pm 0.002$ & $-(a)$ & -(a) \\
\hline $\mathrm{Sb}$ & $0.014 \pm 0.001$ & $0.013^{*}$ & 108 & $\Sigma R E Y^{(b)}$ & 63.7 & & \\
\hline Sc & $0.029 \pm 0.003$ & $0.03 *$ & 97 & $\mathrm{Eu} / \mathrm{Eu}^{*(\mathrm{c})}$ & 0.28 & & \\
\hline $\mathrm{Se}$ & $0.047 \pm 0.003$ & $0.05 \pm 0.009$ & 94 & $\mathrm{Ce} / \mathrm{Ce}{ }^{*(\mathrm{~d})}$ & 0.08 & & \\
\hline Sn & $0.164 \pm 0.015$ & $<0.2^{*}$ & -(a) & $\Sigma \mathrm{LREE} / \Sigma \mathrm{HREE}^{(\mathrm{e})}$ & 14.4 & & \\
\hline $\mathrm{Sr}$ & $25.1 \pm 0.5$ & $25 \pm 2$ & 100 & $\mathrm{Ba} / \mathrm{Eu}^{(\mathrm{f})}$ & 243 & & \\
\hline $\mathrm{Ti}$ & $15.9 \pm 0.6$ & $-(a)$ & -(a) & & & & \\
\hline
\end{tabular}

(a) - not specified.

(b) $\Sigma R E Y$ - sum of all rare earth element concentrations.

(c) Eu / Eu* - europium anomaly (Eu / Eu* = EuNASC / (SmNASC $\times$ GdNASC)0.5).

(d) $\mathrm{Ce} / \mathrm{Ce}^{*}$ - cerium anomaly (Ce $/ \mathrm{Ce}^{*}=\mathrm{CeNASC} /($ LaNASC $\times$ PrNASC)0.5).

(e) $\Sigma$ LREE / $\Sigma$ HREE - ratio of sum of light rare earth and heavy rare earth element concentrations.

(f) $\mathrm{Ba} / \mathrm{Eu}$ - ratio of $\mathrm{Ba}$ and Eu concentrations. 
samples were up to two times lower compared to the Citrus leave $\mathrm{CRM}^{[31]}$ which is reflected in the substantially higher ¿REY in NCS ZC73018, amounting to $2.8 \mathrm{mg} \mathrm{kg}^{-1}$ (Table 2). Also, compared to the average REE concentrations in leaves from organic and conventional citrus systems reported by Turra et al., ${ }^{[23]}$ obtained concentrations for all studied leaf samples are substantially lower (up to an order of magnitude lower).

Compared to other plant species, the REY concentrations found in citrus leaves were lower than the ones reported for forest plants (Betula, Pinus sylvestris, Vaccinium vitis-idaea, V. myrtillus, Deschampsia flexuosa, Polytrichum, Sphagnum) from Germany, ${ }^{[34]}$ comparable or higher than those reported for grass leaves (Agrostis capillary) ${ }^{[35]}$ and higher than REY values reported for cabbage (Brassica oleracea var. capitate). ${ }^{[36]}$ They were also found comparable to REY levels reported for olive leaves grown on reclaimed karst, rendzina, and calcocambisol soil, but lower compared to ones grown on cambisol soil characterised by lower $\mathrm{pH}(4.7-5.8)$ and elevated levels of

Table 4. Comparison of measured element concentrations (mean \pm standard deviation; $n=6$ ) and certified values (with associated uncertainties), expressed both in $\mathrm{mg} \mathrm{kg}^{-1}$, obtained recoveries (\%), and calculated REY fractionation indices in Rye grass (ERM CD281).

\begin{tabular}{|c|c|c|c|c|c|c|c|}
\hline Element & Measured & Certified value & Recovery & Element & Measured & Certified value & Recovery \\
\hline $\mathrm{Al}$ & $56 \pm 3$ & -(a) & -(a) & $\mathrm{Tl}$ & $0.006 \pm 0.001$ & -(a) & -(a) \\
\hline As & $0.040 \pm 0.005$ & $0.042 \pm 0.010$ & 95 & $u$ & $0.003 \pm 0.001$ & -(a) & -(a) \\
\hline $\mathrm{Ba}$ & $12.5 \pm 0.5$ & -(a) & -(a) & v & $0.26 \pm 0.02$ & -(a) & -(a) \\
\hline $\mathrm{Be}$ & $<0.002$ & -(a) & -(a) & $\mathrm{Zn}$ & $29.0 \pm 1.3$ & $30.5 \pm 1.1$ & 93 \\
\hline $\mathrm{Bi}$ & $0.003 \pm 0.001$ & -(a) & -(a) & $\mathrm{Zr}$ & $0.75 \pm 0.05$ & -(a) & -(a) \\
\hline $\mathrm{Cd}$ & $0.114 \pm 0.006$ & $0.12 \pm 0.007$ & 95 & Y & $0.034 \pm 0.002$ & -(a) & -(a) \\
\hline Co & $0.24 \pm 0.01$ & -(a) & $-(a)$ & La & $0.06 \pm 0.005$ & -(a) & -(a) \\
\hline $\mathrm{Cr}$ & $24.2 \pm 1.0$ & $24.8 \pm 1.3$ & 98 & $\mathrm{Ce}$ & $0.11 \pm 0.01$ & -(a) & -(a) \\
\hline Cs & $0.081 \pm 0.002$ & -(a) & -(a) & $\mathrm{Pr}$ & $0.014 \pm 0.002$ & -(a) & -(a) \\
\hline $\mathrm{Cu}$ & $9.7 \pm 0.5$ & $10.2 \pm 0.5$ & 95 & $\mathrm{Nd}$ & $0.16 \pm 0.01$ & -(a) & -(a) \\
\hline $\mathrm{Fe}$ & $172 \pm 10$ & $180^{*}$ & 96 & $\mathrm{Sm}$ & $0.009 \pm 0.002$ & -(a) & -(a) \\
\hline K & $31000 \pm 2000$ & $34000 *$ & 96 & $\mathrm{Eu}$ & $0.021 \pm 0.002$ & -(a) & -(a) \\
\hline $\mathrm{Li}$ & $0.054 \pm 0.007$ & -(a) & -(a) & $\mathrm{Gd}$ & $0.035 \pm 0.002$ & -(a) & -(a) \\
\hline $\mathrm{Mg}$ & $1550 \pm 100$ & $1600^{*}$ & 97 & $\mathrm{~Tb}$ & $0.014 \pm 0.002$ & -(a) & -(a) \\
\hline $\mathrm{Mn}$ & $78.7 \pm 3$ & $82 \pm 4$ & 96 & Dy & $0.018 \pm 0.002$ & -(a) & -(a) \\
\hline Mo & $2.19 \pm 0.07$ & $2.22 \pm 0.12$ & 99 & Ho & $0.011 \pm 0.002$ & -(a) & -(a) \\
\hline $\mathrm{Na}$ & $3900 \pm 250$ & $4000^{*}$ & 98 & $\mathrm{Er}$ & $0.010 \pm 0.002$ & -(a) & -(a) \\
\hline $\mathrm{Ni}$ & $14.7 \pm 0.6$ & $15.2 \pm 0.6$ & 97 & $\mathrm{Tm}$ & $0.016 \pm 0.002$ & -(a) & -(a) \\
\hline $\mathrm{Pb}$ & $1.64 \pm 0.05$ & $1.67 \pm 0.11$ & 98 & $\mathrm{Yb}$ & $0.030 \pm 0.002$ & -(a) & -(a) \\
\hline $\mathrm{Rb}$ & $41.1 \pm 1.4$ & -(a) & -(a) & Lu & $<0.002$ & -(a) & -(a) \\
\hline $\mathrm{Sb}$ & $0.039 \pm 0.002$ & $0.042 \pm 0.007$ & 93 & $\Sigma R E Y^{(b)}$ & 0.54 & & \\
\hline Sc & $0.014 \pm 0.002$ & -(a) & -(a) & $\mathrm{Eu} / \mathrm{Eu}^{*(c)}$ & 5.25 & & \\
\hline $\mathrm{Se}$ & $0.021 \pm 0.002$ & $0.023 \pm 0.004$ & 91 & $\mathrm{Ce} / \mathrm{Ce} \mathrm{e}^{*(\mathrm{~d})}$ & 0.88 & & \\
\hline Sn & $0.067 \pm 0.007$ & $0.062 \pm 0.011$ & 108 & $\Sigma \mathrm{LREE} / \Sigma \mathrm{HREE}^{(\mathrm{e})}$ & 4.1 & & \\
\hline $\mathrm{Sr}$ & $23.7 \pm 0.8$ & -(a) & -(a) & $\mathrm{Ba} / \mathrm{Eu}^{(f)}$ & 595 & & \\
\hline $\mathrm{Ti}$ & $4.5 \pm 0.3$ & -(a) & -(a) & & & & \\
\hline
\end{tabular}

(a) - not specified.

(b) $\Sigma R E Y$ - sum of all rare earth element concentrations.

(c) Eu / Eu* - europium anomaly (Eu / Eu* = EuNASC / (SmNASC $\times$ GdNASC)0.5).

(d) $\mathrm{Ce} / \mathrm{Ce}^{*}$ - cerium anomaly (Ce / Ce* $=\mathrm{CeNASC} /($ LaNASC $\times$ PrNASC) 0.5$)$

(e) $\Sigma$ LREE / $\Sigma$ HREE - ratio of sum of light rare earth and heavy rare earth element concentrations.

(f) $\mathrm{Ba} / \mathrm{Eu}$ - ratio of $\mathrm{Ba}$ and Eu concentrations. 
(a)

NIST SRM 1515

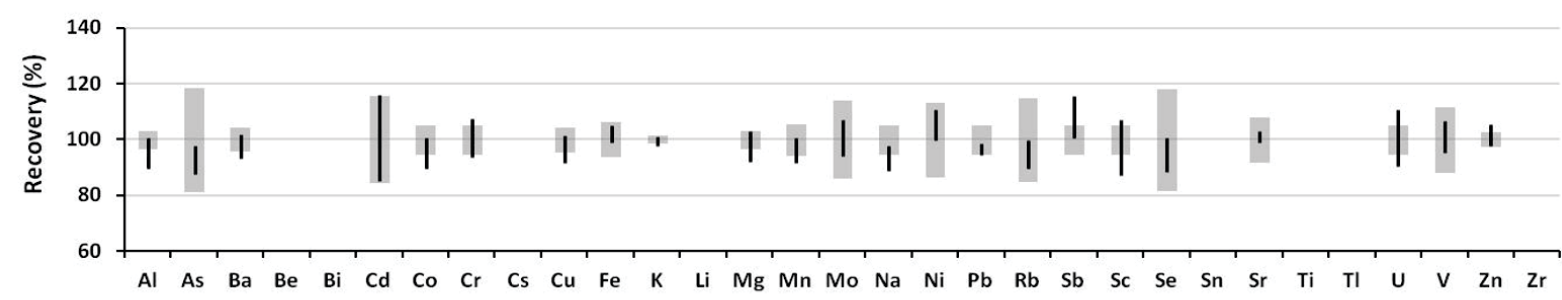

(b)

ERM CD281

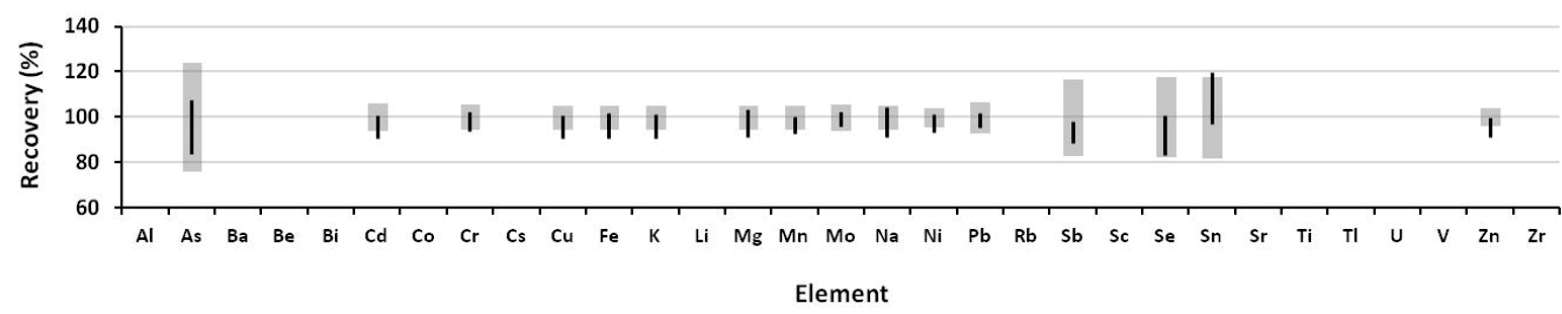

Figure 1. Comparison of measured (indicated by I) and certified (indicated by I) major, minor, and trace elements in (a) Apple leave (NIST SRM 1515) and (b) Rye grass (ERM CD281), presented as recovery ranges.

Al and P. ${ }^{[37]}$ Even though the influence of soil characteristics on plant uptake of REY in a natural environment is still largely unknown, the study of Pošćić et al.[37] suggests that the specific local soil condition, such as $\mathrm{pH}$ and phosphorus availability, could explain most of the REY variability in plants, including also leaves.

Interestingly, the REY levels in studied citrus leaves were substantially lower or comparable to the lowest values reported by Miao et al. [38] for leaves of Eucalyptus globulus Labill, Dicranopteris dichotoma, and Pinus massoniana, although the concentrations of REY in soils reported by these authors are comparable to REY levels in soils from Croatia. ${ }^{[37,39,40]}$ Thereby, it should be noted that the concentration levels of major and trace elements recorded in the ornamental plant substrate ( $\mathrm{pH}$ 5.0-6.5) available on the Croatian market ${ }^{[41]}$ are comparable or even lower than those in Croatian soils. ${ }^{[40]}$

Furthermore, the general order of REEs concentrations in different compartments of the citrus system was reported to decrease in the following order, soil > leaf $>$ peel $>$ pulp $>$ seed $>$ juice. ${ }^{[23]}$

In all investigated samples light rare earth elements, i.e. elements from La to Gd (LREE), were found to be more abundant compared to heavy rare earth elements, i.e. elements from Tb to Lu (HREE), with average LLREE / $\Sigma$ HREE ratios of $11.6,15.5$ and 43.4 for tangerine, orange and lemon leaf samples, respectively (Table 5). Despite the differences in total REY, the LLREE / IHREE in NCS ZC73018 (15.1) is comparable to the average value obtained for orange leave (Table 1). Ratios similar to those obtained for tangerine and orange leaves were also reported for

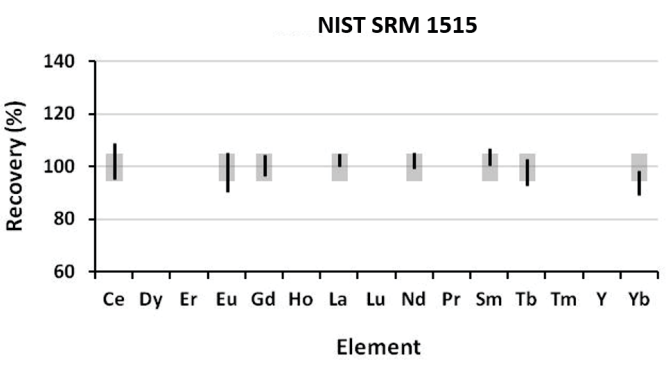

Figure 2. Comparison of measured (indicated by I) and certified (indicated by I) rare earth elements in Apple leave (NIST SRM 1515), presented as recovery ranges.

Eucalyptus globulus Labill, Dicranopteris dichotoma, and Pinus massoniana leaves from South China ${ }^{[38]}$.

Citrus leaf samples exhibited a slightly positive to positive europium anomaly $\left(\mathrm{Eu} / \mathrm{Eu}^{*}=\mathrm{Eu}_{\mathrm{NASC}} /\right.$ $\left.\left(\mathrm{Sm}_{\text {NASC }} \times \mathrm{Gd}_{\text {NASC }}\right)^{0.5}=1.05-2.82\right)$, and a negative to slightly negative cerium anomaly $\left(\mathrm{Ce} / \mathrm{Ce}^{*}=\mathrm{Ce}_{\mathrm{NASC}} /\right.$ $\left.\left(\text { La }_{\text {NASC }} \times \operatorname{Pr}_{\text {NASC }}\right)^{0.5}=0.55-0.99\right)$ (Table 5); both of which are in accordance with values obtained for NCS ZC73018 (Table 1). Interestingly, the lowest average values for both anomalies were observed for the lemon leaf samples ( $\mathrm{Eu} / \mathrm{Eu}^{*}=$ 1.29 and $\mathrm{Ce} / \mathrm{Ce}^{*}=0.56$ ). The orange leaves, on the other hand, showed higher average values of both anomalies (Eu / $\mathrm{Eu}^{*}=2.35$ and $\mathrm{Ce} / \mathrm{Ce}^{*}=0.90$ ), while the highest average values were observed for tangerine leaves $\left(\mathrm{Eu} / \mathrm{Eu}^{*}=2.41\right.$ and $\mathrm{Ce} / \mathrm{Ce} \mathrm{e}^{*}=0.95$ ). The predominance of LREE in citrus leaves, accompanied by negative Ce anomaly, was also reported by Turra et al. ${ }^{[23]}$. 
Table 5. Measured element concentrations (average and standard deviation), expressed as $\mathrm{mg} \mathrm{kg}^{-1}$, in different citrus leaves, ${ }^{[31]}$, and calculated REY fractionation indices.

\begin{tabular}{|c|c|c|c|}
\hline Element & Orange leave & Lemon leave & Tangerine leave \\
\hline Y & $0.058 \pm 0.015$ & $0.108 \pm 0.013$ & $0.026 \pm 0.001$ \\
\hline La & $0.082 \pm 0.020$ & $0.583 \pm 0.070$ & $0.038 \pm 0.004$ \\
\hline $\mathrm{Ce}$ & $0.145 \pm 0.038$ & $0.461 \pm 0.051$ & $0.074 \pm 0.008$ \\
\hline $\mathrm{Pr}$ & $0.017 \pm 0.005$ & $0.063 \pm 0.006$ & $0.009 \pm 0.001$ \\
\hline $\mathrm{Nd}$ & $0.067 \pm 0.020$ & $0.225 \pm 0.031$ & $0.038 \pm 0.002$ \\
\hline Sm & $0.013 \pm 0.004$ & $0.034 \pm 0.003$ & $0.008 \pm 0.001$ \\
\hline Eu & $0.006 \pm 0.002$ & $0.009 \pm 0.001$ & $0.004 \pm 0.001$ \\
\hline $\mathrm{Gd}$ & $0.015 \pm 0.001$ & $0.019 \pm 0.001$ & $0.009 \pm 0.001$ \\
\hline $\mathrm{Tb}$ & $0.002 \pm 0.001$ & $0.003 \pm 0.001$ & $0.001 \pm 0.0003$ \\
\hline Dy & $0.008 \pm 0.001$ & $0.014 \pm 0.002$ & $0.006 \pm 0.001$ \\
\hline Ho & $0.002 \pm 0.001$ & $0.002 \pm 0.001$ & $0.001 \pm 0.0003$ \\
\hline $\mathrm{Er}$ & $0.005 \pm 0.001$ & $0.006 \pm 0.001$ & $0.004 \pm 0.001$ \\
\hline $\mathrm{Tm}$ & $0.001 \pm 0.0003$ & & \\
\hline $\mathrm{Yb}$ & $0.005 \pm 0.002$ & $0.005 \pm 0.001$ & $0.003 \pm 0.001$ \\
\hline Lu & $0.001 \pm 0.0003$ & $0.001 \pm 0.0003$ & $0.001 \pm 0.0003$ \\
\hline$\sum R E Y^{(a)}$ & $0.421 \pm 0.111$ & $1.54 \pm 0.174$ & $0.220 \pm 0.018$ \\
\hline $\mathrm{Eu} / \mathrm{Eu}^{*(\mathrm{~b})}$ & $2.35 \pm 0.43$ & $1.29 \pm 0.25$ & $2.41 \pm 0.64$ \\
\hline $\mathrm{Ce} / \mathrm{Ce}{ }^{*(c)}$ & $0.90 \pm 0.02$ & $0.56 \pm 0.002$ & $0.95 \pm 0.24$ \\
\hline$\Sigma$ LREE / $\Sigma \mathrm{HREE}^{(\mathrm{d})}$ & 15.5 & 43.4 & 11.6 \\
\hline $\mathrm{Ba} / \mathrm{Eu}^{(\mathrm{e})}$ & 2483 & 2044 & 2550 \\
\hline \multicolumn{4}{|c|}{$\begin{array}{l}\text { b) Eu / Eu* - europium anomaly (Eu / Eu* = EuNASC / (SmNASC } \times \\
\text { GdNASC)0.5). }\end{array}$} \\
\hline \multicolumn{4}{|c|}{$\begin{array}{l}\text { (c) Ce / Ce* - cerium anomaly (Ce / Ce } e^{*}=\text { CeNASC / (LaNASC } \times \\
\text { PrNASC) } 0.5) \text {. }\end{array}$} \\
\hline \multicolumn{4}{|c|}{$\begin{array}{l}\text { d) } \Sigma \text { LREE / } \Sigma \text { HREE - ratio of sum of light rare earth and heavy rare } \\
\text { earth element concentrations. }\end{array}$} \\
\hline
\end{tabular}

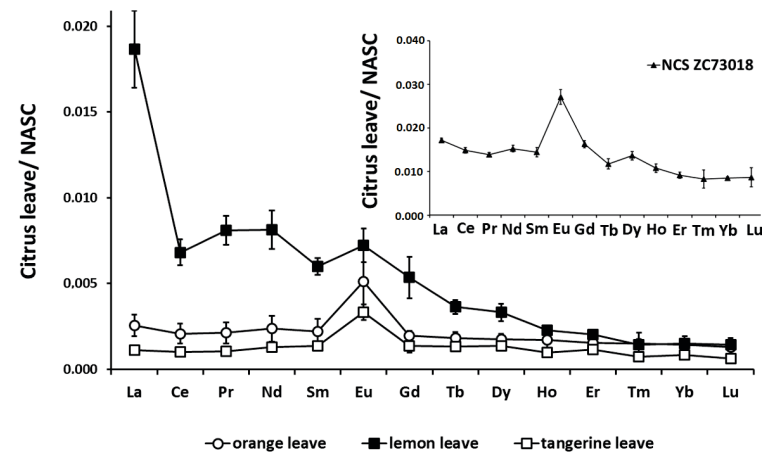

Figure 3. NASC-normalized REE patterns of citrus leaf samples, including the CRM NCS ZC73018.
Prevalence of LREE, along with positive Eu and negative Ce anomaly, is reflected in the average REE patterns of studied citrus leaves (Figure 3), normalized to the average composition of North American Shale Composite (NASC). ${ }^{[42]}$

The normalized curves of the orange and tangerine leaves are similar to that of CRM NCS ZC73018 (Figure 3), except for the less pronounced Eu anomaly, while the normalized curve of the lemon leaves in more inclined, showing a decrease in normalized values from LREE to HREE. Compared to the normalized curves of citrus leaves reported by Turra et al., ${ }^{[23]}$ all curves obtained in this study are less inclined and have significantly stronger Eu anomalies. The positive bias for the Eu anomaly could be, at least partly, attributed to the interferences from oxide species, specifically $\mathrm{BaO}$. Namely, in case of high $\mathrm{Ba}$ concentrations and an abundance of $\mathrm{Ba} / \mathrm{Eu}>1000$, notable $\mathrm{BaO}$ interference on both $\mathrm{Eu}$ isotopes $\left({ }^{151} \mathrm{Eu}\right.$ and ${ }^{153} \mathrm{Eu}$ ) and occurrence of false-positive $\mathrm{Eu}$ anomaly was observed in the samples. ${ }^{[43]}$ In this study, Ba / Eu > 2000 was observed for all citrus leaf samples, including the NCS ZC73018 (Table 1 and Table 5). Usually switching to highresolution (HR) mode improves the Eu determination and elimination of $\mathrm{BaO}$ interference; ${ }^{[43]}$ however, in this case, low levels of Eu in all studied samples prevented the use of HR mode. Therefore, caution is advised when applying low and medium-resolution mode for quantification of $\mathrm{Eu}$ in biota samples containing high levels of barium.

Although the remaining two reference materials (NIST SRM 1515 and ERM CD281) showed much lower $\mathrm{Ba} /$ Eu ratios, the other calculated parameters indicate high variability between plant species not only in terms of REY fractionation but also in their total accumulation (Table 3 and Table 4). Thereat, Apple leave (NIST SRM 1515) displayed up to two orders of magnitude higher REY values ( $\sum R E Y=63.7$, Table 3 ) compared to citrus leaves. Given that the species in the genus Malus, along with species in the genus Citrus, are among the most commonly grown tree species, further research is needed on this topic.

\section{CONCLUSION}

Investigated citrus leaves displayed substantially lower REY levels compared to the literature available for the citrus system. However, they displayed similar fractionation, i.e. the prevalence of LREE, positive $\mathrm{Eu}$ and negative $\mathrm{Ce}$ anomaly. Compared to the certified reference material for citrus leaves (NCS ZC73018), ${ }^{[1]}$ studied citrus leaves displayed overall lower REY concentrations.

The presented data also include concentrations of 46 elements in two biological reference materials, Apple leave (NIST SRM 1515), and Rye grass (ERM CD281), determined by HR-ICP-MS. In comparison with the certified and/or 
informative values available for these reference materials, additional information for 14 elements in NIST SRM 1515, and 30 elements for ERM CD281, including the REYs, was provided, extending their application in environmental and food studies.

\section{REFERENCES}

[1] J. Carbonell-Caballero, R. Alonso, V. Ibãnez, J. Terol, M. Talon, J. Dopazo, Mol. Biol. Evol. 2015, 32, 20152035. https://doi.org/10.1093/molbev/msv082

[2] H.-J. Su, S. A. Hogenhout, A. M. Al-Sadi, C.-H. Kuo, PLOS ONE 2014, 9, e113049.

https://doi.org/10.1371/journal.pone.0113049

[3] G. Arumugam, M. K. Swamy, U. R. Sinniah, Molecules 2016, 21, 369.

https://doi.org/10.3390/molecules21040369

[4] D. J. Mabberley, Blumea, 2004, 49/2-3, 481-498. https://doi.org/10.3767/000651904X484432

[5] E. Tripoli, M. L. Guardia, S. Giammanco, D. D. Majo, M. Giammanco, Food Chem. 2007, 104, 466-479. https://doi.org/10.1016/j.foodchem.2006.11.054

[6] C. A. Ezeabara, C. U. Okeke, B.O. Aziagba, C. V. Ilodibia, A. N. Emeka, Int. Res. J. Pure Appl. Chem. 2014, 4, 137-143.

[7] M. M. Özcan, M. Harmankaya, Environ. Monit. Assess. 2012, 184, 313-320.

https://doi.org/10.1007/s10661-011-1969-y

[8] O. R. Raja, S. Sobhanardakani, M. Cheraghi, Environ. Health Eng. Manag. J. 2016, 3, 131-135. https://doi.org/10.15171/EHEM.2016.11

[9] Y. S. Hong, J.Y.Choi, E. Y. Nho, I. M. Hwang, N. Khan, N. Jamila, K. S. Kim, J. Sci. Food Agric. 2018, 99/4, 1870-1879. https://doi.org/10.1002/jsfa.9382

[10] Z. L. He, X. E. Yang, P. J. Stoffella, J. Trace Elem. Med. Biol. 2005, 19/2-3, 125-140.

https://doi.org/10.1016/j.jtemb.2005.02.010

[11] P. Babula, V. Adam, R. Opatrilova, J. Zehnalek, L. Havel, R. Kizek, Environ. Chem. Lett. 2008, 6, 189213. https://doi.org/10.1007/s10311-008-0159-9

[12] R. A. Wuana, F.E. Okieimen, ISRN Ecol. Int. 2011, 402647, 1. https://doi.org/10.5402/2011/402647

[13] H. Ali, E. Khan, Environ. Chem. Lett. 2017, 15, 329346. https://doi.org/10.1007/s10311-016-0601-3

[14] A. Schützendübel, A. Polle, J. Exp. Bot. 2002, 53, 1351-1365. https://doi.org/10.1093/jexbot/53.372.1351

[15] A. Kabata-Pendias, H. Pendias, Trace Elements in Soils and Plants, CRC Press, Boca Raton, London, New York, Washington D.C. 2001, p. 403. https://doi.org/10.1201/9781420039900

[16] H. Ali, E. Khan, I. Ilahi, J Chem. 2019, 6730305, 1. https://doi.org/10.1155/2019/6730305
[17] Ž. Fiket, G. Medunić, Ž. Vidaković-Cifrek, P. Jezidžić, P. Cvjetko, Environ. Sci. Pollut. Res. 2019, 27, 66136627. https://doi.org/10.1007/s11356-019-07396-w

[18] A. Stapulionytè, V. Kleizaitè, R. Šiukšta, D. Žvingila, R. Taraškevičius, T. Čèsnienė, Mutat. Res. / Genet. Toxicol. Environ. Mutagen. 2019, 842, 102-110. https://doi.org/10.1016/j.mrgentox.2019.01.001

[19] F. De Nicola, V. Spagnuolo, D. Baldantoni, S. L. Alfani, L. Bargagli, F. Monaci, S. Terracciano, S. Giordano, Chemosphere 2013, 92/9, 1224-1230.

https://doi.org/10.1016/j.chemosphere.2013.04.050

[20] G. Tyler, Plant Soil 2004, 267, 191-206. https://doi.org/10.1007/s11104-005-4888-2

[21] Ž. Fiket, G. Medunić, M. Furdek Turk, M. Ivanić, G. Kniewald, Chemosphere 2017, 179, 92-100. https://doi.org/10.1016/j.chemosphere.2017.03.089

[22] H. R. El-Ramady, A contribution on the bio-actions of rare earth elements in the soil/plant environment [Dissertation]. Julius Kühn-Institut, Berlin 2008.

[23] C. Turra, E. A. De Nadai Fernandes, M. Arruda Bacchi, G. A. Sarriés, F. Barbosa Júnior, A. E. Lai Reyes, J. Plant Nutr. 2013, 36/5, 762-771. https://doi.org/10.1080/01904167.2012.754040

[24] R. J. Bennet, C. M. Breen, Environ. Exp. Bot. 1992, 32, 365-376. https://doi.org/10.1016/0098-8472(92)90049-8

[25] Y. Z. Wei, X. B. Zhou, J. Rare Earth. 2000, 18, 57-61.

[26] H. Zhengyi, H. Richter, G. Sparovek, E. Schnug, J. Plant Nutr. 2004, 27/1, 183-220. https://doi.org/10.1081/PLN-120027555

[27] M. Barbieri, J. Geol. Geophys. 2016, 5/1, 237. https://doi.org/10.4172/2381-8719.1000237

[28] Z. Yuan, J. Yao, F. Wang, Z. Guo, Z. Dong, F. Chen, Y. Hu, G. Sunahara, Environ. Monit. Assess. 2016, 189, 25. https://doi.org/10.1007/s10661-016-5755-8

[29] R. Zinkutè, R. Taraškevičius, M. Jankauskaitè, Ž. Stankevičius, J. Soil Sediment. 2016, 17/2, 440-452. https://doi.org/10.1007/s11368-016-1549-4

[30] Ž. Fiket, N. Mikac, G. Kniewald, Geostand. Geoanal. Res. 2017, 41, 123. https://doi.org/10.1111/ggr.12129

[31] Ž. Fiket, M. Furdek Turk, I. Biljan, in Proceedings of the 9th International Congress of Food Technologists, Biotechnologists and Nutritionists (Eds: K. Kovačević Ganić, V. Dragović-Uzelac, S. Balbino), Zagreb, 2018, pp. 94-97.

[32] V. Filipović Marijić, B. Raspor, Water Air Soil Poll. 2012, 223, 4769-4783. https://doi.org/10.1007/s11270-012-1233-2

[33] J. Ivanova, S. Korhammer, R. Djingova, H. Heidenreich, B. Markert, Acta Part B At. Spectrosc. 2001, 56, 3-12. https://doi.org/10.1016/S0584-8547(00)00281-0 
[34] B. Markert, Z. D. Li, Sci. Total Environ. 1991, 103, 27-35. https://doi.org/10.1016/0048-9697(91)90350-N

[35] G. Tyler, T. Olsson, Plant Soil. 2001, 230, 307-321. https://doi.org/10.1023/A:1010314400976

[36] A. Bibak, S. Stürup, L. Knudsen, V. Gundersen, Commun. Soil Sci Plant. 1999, 30/17-18, 2409-2418. https://doi.org/10.1080/00103629909370382

[37] F. Pošćić, M. Žanetić, Ž. Fiket, M. Furdek Turk, N. Mikac, N. Bačić, M. Lučić, M. Romić, H. Bakić., M. Jukić Špika, B. Urlić, M. Runjić, G. Vuletin Selak, E. Vitanović, T. Klepo, J. Rošin, Z. Rengel, S. Perica, Plant Soil. 2020, 448, 133-151. https://doi.org/10.1007/s11104-019-04418-x

[38] L. Miao, R. Xu, Y. Ma, Z. Zhu, J. Wang, R. Cai, Y. Chen, Environ. Geol. 2008, 56, 225-235. https://doi.org/10.1007/s00254-007-1157-0

[39] R. Salminen, M.J. Batista, M. Bidovec, A. Demetriades, B. De Vivo, W. De Vos, M. Duris, A Gilucis, V. Gregorauskiene, J. Halamic, P. Heitzmann, A. Lima, G. Jordan, G. Klaver, P. Klein, J. Lis, J.
Locutura, K. Marsina, A. Mazreku, P. J. O'Connor, S.Å. Olsson, R. T. Ottesen, V. Petersell, J. A. Plant, S. Reeder, I. Salpeteur, H. Sandström, U. Siewers, A. Steenfelt, T. Tarvainen, FOREGS Geochemical Atlas of Europe, Part 1: Background Information, Methodology and Maps. Geological Survey of Finland, Espoo, 2005.

http://www.gtk.fi/publ/foregsatlas/

[40] J. Halamić, S. Miko (Eds.) Geochemical Atlas of the Republic of Croatia, Croatian Geological Survey, Zagreb, 2009, p. 87.

[41] V. Bermanec, Ž. Vidaković-Cifrek, Ž. Fiket, M. Tkalec, Š. Kampić, G. Kniewald. Environ. Earth Sci. 2016, 75/1, 32.

https://doi.org/10.1007/s12665-015-4814-8

[42] P. L. Gromet, P. F. Dymek, L. A. Haskin, R. L. Korotev, Geochim. Cosmochim. Acta. 1984, 48, 2469-2482. https://doi.org/10.1016/0016-7037(84)90298-9

[43] R. L. Thompson, T. Bank, E. Roth, E. Granite, Fuel 2016, 185, 94-101.

https://doi.org/10.1016/j.fuel.2016.07.093 